\title{
HLA and Insulin-dependent Diabetes in South African Negroes
}

\author{
M. G. Hammond ${ }^{1}$, A. C. Asmal', and M. A. K. Omar ${ }^{2}$ \\ ${ }^{1}$ Natal Institute of Immunology and ${ }^{2}$ University of Natal Medical School, Durban, South Africa
}

Summary. The HLA antigens of 57 South African negroes with juvenile-onset, insulin-dependent diabetes were determined. The frequency of B8 was increased $(29.8 \%$ vs $13.9 \%)$ as was the frequency of B14 $(17.5 \%$ vs $6.1 \%)$. The frequency of patients with either one of these cross-reactive antigens was significantly increased after correction for the number of antigens tested $(45.6 \%$ vs $19.2 \%, \mathrm{P}$ (corrected) $<0.005)$.

Key words: HLA, insulin-dependent diabetes, negroes.

Numerous studies of the HLA system in diabetes have shown clear associations between insulindependent diabetes mellitus (IDDM) and certain HLA antigens. Increased frequencies of HLA B8, B15, B18, Cw3, Dw3, Dw4, DRw3 and DRw4 have been found in white Caucasian populations with this disease [1]. An association between HLA B8 and IDDM has also been found in South Africa Indians [2] and in American Blacks [3, 4], but not in Japanese with IDDM [5, 6].

\section{Materials and Methods}

The diabetic patients attended the Diabetic Clinic of the King
Edward VIII Hospital, Durban which is the main teaching hospital
of the University of Natal Medical School. The patients were
characterised by an acute onset of illness below 35 years old, and a
dependence on insulin for control of symptoms and prevention of
ketosis [7]. They were typed over a two year period for the HLA-
A-B-C antigens and the frequencies were compared with those
found in a healthy control population, many of whom were typed
for International Workshops [8,9]. The Negro population of Dur-
ban consists mainly of Zulus and the patients and controls studied
by us were of pure descent. A total of 180 antisera were used in a
two-stage microlymphocytotoxicity test [10] to determine the HLA antigens of 57 Negroes with IDDM. Lymphocytes were isolated on a Ficoll-Hypaque density gradient [11]. Frequency differences were tested for significance with a $\mathrm{X}^{2}$ test (without Yates' correction) and the resulting probabilities corrected by multiplication by the number of antigens tested.

\section{Results}

Table 1 shows the antigen frequencies in the IDDM patients compared with the controls. The distribution of alleles at the A and B loci conform to HardyWeinberg equilibrium.

There were no significant differences between diabetics and control subjects at the $\mathrm{A}$ and $\mathrm{C}$ loci. The frequency of HLA B8 was increased in the diabetics $(29.8 \%)$ compared to the controls $(13.9 \%)$ but this was not significant after correction for the number of antigens tested. The frequency of HLA$\mathrm{B} 14$, on the other hand, was significantly increased even after correction $(17.5 \%$ vs $6.1 \%, \mathrm{P}$ (corrected) $<0.04$ ). As HLA-B8 and B14 form part of a crossreacting group, the number of patients and controls with either of these antigens were compared. The difference in the frequencies $(45.6 \%)$ was highly significant $\left(\mathrm{P}_{\mathrm{c}}<0.004\right)$. The relative risk $(3.5)$ was about the same as for B14 alone (3.3) but greater than the relative risk for $\mathrm{B} 8$ alone (2.6).

There was a slightly stronger negative association between Bw42 and IDDM. The relative risk was 0.25 and the uncorrected $p<0.005$. This was no longer significant after correction for the number of antigens tested.

\section{Discussion}

Nerup et al. [12] discuss the possibility that there are two genes conferring increased risk of IDDM: one associated with $\mathrm{B} 8$ and the other with $\mathrm{B} 15$ or B18. In 
Table 1. Percentage frequency of HLA antigens in Negroes with insulin-dependent diabetes mellitus (IDDM)

\begin{tabular}{|c|c|c|c|c|c|}
\hline HLA & $\begin{array}{l}\text { Control } \\
n=756\end{array}$ & $\begin{array}{l}\text { IDDM } \\
\mathrm{n}=57\end{array}$ & & $\begin{array}{l}\text { Control } \\
\mathrm{n}=756\end{array}$ & $\begin{array}{l}\text { IDDM } \\
\mathrm{n}=57\end{array}$ \\
\hline $\mathrm{A} 1$ & 5.8 & 7.0 & B7 & 16.0 & 22.8 \\
\hline $\mathrm{A} 2$ & 20.1 & 14.0 & B8 & 13.9 & $29.8^{\mathrm{a}}$ \\
\hline A3 & 13.5 & 10.5 & B13 & 4.8 & 3.5 \\
\hline A11 & 0.1 & 0 & B14 & 6.1 & $17.5^{\mathrm{b}}$ \\
\hline Aw23 & 19.2 & 26.3 & B15 & 5.8 & 1.8 \\
\hline Aw24 & 3.3 & 3.5 & B16 & 2.4 & 3.5 \\
\hline $\mathrm{A} 25$ & 13.9 & 5.3 & B17 & 38.1 & 21.1 \\
\hline A26 & 7.5 & 7.0 & B18 & 3.8 & 5.3 \\
\hline A28 & 20.0 & 24.6 & Bw21 & 0.5 & 1.8 \\
\hline A29 & 16.7 & 12.3 & Bw22 & 0 & 0 \\
\hline Aw30 & 39.6 & 36.8 & B27 & 0.3 & 0 \\
\hline Aw31 & 12.6 & 10.5 & Bw35 & 7.3 & 3.5 \\
\hline Aw32 & 1.4 & 8.8 & B37 & 0 & 0 \\
\hline $\mathrm{Aw} 33^{\mathrm{d}}$ & 2.7 & 3.5 & Bw60 & 1.6 & 3.5 \\
\hline Only one & 23.6 & 29.8 & Bw61 & 0 & 0 \\
\hline $\begin{array}{l}\text { antigen } \\
\text { detected }\end{array}$ & & & $\mathrm{Bw} 41^{\mathrm{d}}$ & 2.1 & 3.5 \\
\hline $\mathrm{Cw} 1^{\mathrm{d}}$ & 0 & 1.8 & Bw42 & 27.7 & $8.8^{\mathrm{a}}$ \\
\hline $\mathrm{Cw} 2^{\mathrm{d}}$ & 18.5 & 21.1 & Bw44 & 16.0 & 14.0 \\
\hline $\mathrm{Cw} 3^{\mathrm{d}}$ & 9.6 & 17.5 & Bw45 & 6.4 & 10.5 \\
\hline $\mathrm{Cw} 4^{\mathrm{d}}$ & 15.8 & 17.5 & Bw51 & 2.7 & 0 \\
\hline \multirow[t]{2}{*}{$\mathrm{Cw}^{\mathrm{d}}$} & 4.1 & 3.5 & Bw52 & 0 & 0 \\
\hline & & & Bw53 & 3.4 & 3.5 \\
\hline B8+B14 & 19.2 & $45.6^{\mathrm{c}}$ & $\begin{array}{l}\text { Only one } \\
\text { antigen } \\
\text { detected }\end{array}$ & 41.1 & 45.6 \\
\hline
\end{tabular}

${ }^{\text {a } \mathrm{P}<0.005}$

${ }^{\mathrm{b}} \mathrm{P}<0.001$

${ }^{c} \mathrm{P}<0.0001$

${ }^{d} \mathrm{~N}=146$ (Number of controls)

all the Caucasian populations studied to date the association with $\mathrm{B} 8$ has been a constant finding. The relationship with B15 and/or B18 has been confined to certain population groups. The association of these antigens appears to be secondary to the increased frequency of DRw3/Dw3 and DRw4/Dw4 $[1,13]$.

This study has demonstrated an increased frequency of B8 and of B14 in South African Negroes with IDDM. Since these antigens form a cross-reacting group it is probable that the same susceptibility gene is associated with either of these antigens in Negroes. Alternatively, it may be postulated that another susceptibility gene, associated with $\mathrm{B} 15$ or B18 in Caucasians, is linked to B14 in Negroes. This latter explanation seems less likely.

The Bw42 antigen has been detected only in Black populations. It is, however, one of the crossreacting antigens associated with $\mathrm{B} 7$ which may be linked to some protective mechanism against IDDM [12]. The protective effect is not associated with HLA B7 in Negroes, indeed, the frequency of the antigen is greater in the IDDM group than in the controls. The relatively low frequency of $\mathrm{Bw} 42$ in Negroes with IDDM may have a bearing on the low prevalence of IDDM in Negroes. Alternatively, it may be a reflection of the increased frequency of B8 and B14. The difficulties of establishing the significance of a negative association between HLA and disease have been discussed by Svejgaard et al. [13].

Acknowledgements. The authors acknowledge the expert technical assistance of Mrs. F. Buckle and Mr. J. Govender. This work was supported in part by a grant from the South African Medical Research Council (M. G. H.).

\section{References}

1. Ryder LP, Andersen E, Svejgaard A (1979) HLA and disease registry, third Rep. Munksgaard, Copenhagen

2. Hammond MG, Asmal AC (1979) HLA and insulin-dependent diabetes in South African Indians. Tissue Antigens

3. Cahill GF (1979) Human evolution and insulin dependent (IDD) and non-insulin dependent diabetes (NIDD). Metabolism 28: 389-393

4. Duquesnoy RJ, MacDonald MJ, Mullins P, Hackbarth SA, Trasman HS, Levitsky LL (1979) Increased frequency of HLA-Dw3 in North American Black patients with juvenile onset diabetes. Tissue Antigens 13: 369-372

5. Kawa A, Nakazawa M, Sakaguchi S, Nakamura S, Komo Y, Hazeki H, Kanehisa T (1977) HLA system in Japanese patients with diabetes mellitus. Diabetes 26: 591-595

6. Nakao Y, Fukunishi T, Koide M, Akasawa K, Ikeda M, Yahata M, Imura H (1977) HLA antigens in Japanese patients with diabetes mellitus. Diabetes 26: 736-739

7. West KJ (1978) Epidemiology of diabetes and its vascular lesions. Elesevier, New York

8. Hammond MG, Appadoo G, Brain P (1975) HLA antigens in Bantu and Indians. In: Kissmeyer-Nielsen F (ed) Histocompatibility testing 1975. Munksgaard, Copenhagen, p 173-178

9. Hammond MG, Appadoo B, Brain P (1977) HLA in NonCaucasian populations. In: Bodmer WF (ed) Histocompatibility testing 1977. Munksgaard, Copenhagen, p 407-408

10. Terasaki PI, McClelland JD (1964) Microdroplet assay of human serum cytotoxins. Nature 204: 998-1000

11. Boyum A (1968) Separation of leucocytes from blood and bone marrow. Scand J Clin Lab Invest 21: 97

12. Nerup J, Cathelineau Cr, Seignalet J, Thomsen M (1977) HLA and endocrine disease. In: Dausset J, Svejgaard A (eds) HLA and disease. Munksgaard, Copenhagen, $\mathrm{p}$ 149-167

13. Christy M, Green A, Christau B, Kromann H, Nerup J, Platz P, Thomsen M, Ryder LP, Svejgaard A (1979) Studies of the HLA system and insulin-dependent diabetes mellitus. Diabetes Care 2: 209-214

14. Svejgaard A, Jersild C, Staub Nielsen L, Bodmer WF (1974) HLA antigens and disease. Statistical and genetical considerations. Tissue Antigens 4: 95-105

Received: December 20, 1979,

and in revised form: March 18, 1980

M. G. Hammond

Natal Institute of Immunology

P. O. Box 2356

Durban, 4000

South Africa 